\title{
DETERMINATION OF GSM SIGNAL PENETRATION LOSS IN SOME SELECTED BUILDINGS IN RIVERS STATE, NIGERIA
}

\author{
P. Elechi ${ }^{1}$ and P. O. Otasowie ${ }^{2, *}$ \\ 1 Dept of Electrical Engr'G, Rivers State Univ. of SCience and TeCh., Port Harcourt, Rivers State. NiGERIA.

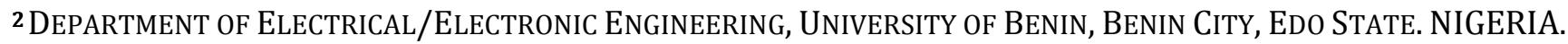 \\ Email addresses:1elechipromise@ust.edu.ng, ${ }^{2}$ potasowie@yahoo.co.uk
}

\begin{abstract}
The qualities of indoor signal reception are governed by the mechanism of reflection, refraction, diffraction and scattering of signal propagation through buildings which are dependent on the material of the building structure. These indoor outages can be traced to building penetration loss. Penetration loss depends on the type of building material used. This research work is a determination of signal penetration loss in some selected buildings in Rivers state, Nigeria. Global system for mobile communication (GSM) signals of MTN, GLOBACOM, AIRTELand ETISALAT networks were measured using Radio Frequency Signal Tracker in five different buildings (mud house with thatched roof, mud house/rusted corrugated iron sheet roof, sandcrete building/rusted corrugated iron sheet roof, sandcrete building/unrusted corrugated iron sheet roof and building with alucoboard wall cladding) in Port Harcourt metropolis in Nigeria. The results showed that buildings with alucoboard wall cladding has the highest GSM signal penetration loss while the sandcrete building/unrushed corrugated iron sheet roof has the lowest GSM penetration signal loss.
\end{abstract}

Keywords: GSM signal, building, frequency, penetration loss.

\section{STATEMENT OF PROBLEM}

With the advent of GSM in Nigeria, telecommunication services have been brought nearer to an average individual in the country [1]. However GSM is not without problems as it is not an uncommon sight to see a mobile user at some location move from inside to outside a building in order to have an uninterrupted communication. This is because when a GSM signal passes through a medium not transparent to electromagnetic wave; it experiences a loss known as penetration loss. This work is to find out the level of penetration loss in buildings and suggest ways for improvement of (GSM) indoor signal quality.

\subsection{Introduction}

Mobile and wireless communications are a basic need in modern society. Statistics show that in many countries, mobile phone penetration is already higher than the fixed one. Mobile phones are used everywhere, not only outdoor, but also more and more indoor. In these environments, customers demand a good coverage and good quality of service. Penetration loss affects the signal strength received inside a building from an external transmitter (outdoor-to-indoor reception). Penetration loss contributes to the overall loss of a communication link [2].

GSM signal strength usually suffer losses due to free space, diffraction, refraction, human activities and other factors [3-6]. These affect the overall performance of the GSM signal inside building. Most mobile radio systems operate in areas where there is no direct line-of-sight path between the transmitting and the receiving antennas. Due to multiple reflections from various objects, the electromagnetic waves travel along different paths of varying lengths to the receiver simultaneously [7]. The interaction between these waves therefore causes multipath fading, resulting in increased path loss as the distance between the transmitter and receiver increases [2], [8-9]. Building penetration loss accounts for the increase in attenuation of the received signal observed when the mobile is moved from outside to inside a building [6]. Some researchers have suggested that building penetration loss decreases with frequency over a 
certain range while specific losses through materials increase with frequency [8]. This work will analyse the losses caused by building structures such as non-linear variation of material and material thickness over signal frequency and the average penetration loss.

This paper is aimed at studying and analysing the effect of building walls and roof on (GSM) signals. Specifically, this paper will: Conduct measurements to analyse (GSM) signal losses using Radio Frequency Signal Tracker software installed in a Tecno tablet and used on mud building/rusted corrugated iron sheet roof, mud building with thatched roof, Sandcrete building/rusted corrugated iron sheet roof, sandcrete building/unrusted corrugated iron sheet roof and Building with Aluco board wall cladding, as well as their internal wall and floor tiles and ceilings.

The measurement results were used to analyse the penetration loss for the (GSM) network providers (MTN, Globacom, Airtel and Etisalat) in Port Harcourt, Elele, Omoku and Emohua.

The least square method of statistics was used to approximate the set of generated data and to form a correlation to predict the attenuation rate over measurement distances.

\subsection{Review of Recent Related Work}

Several research studies of (GSM) signal penetration losses due to different materials such as trees, buildings, rivers etc. have been carried out by different authors in the past. Some of these works were reviewed and compared with our work.[5] conducted a study of the extra signal attenuation due to building penetration associated to path loss from the Base Stations to Mobile Terminals, for different types of buildings and rooms for (GSM) (900 and $1800 \mathrm{MHz}$ ) and Universal Mobile Telecommunication Systems (UMTS). In their study, a statistical model for the signal attenuation through building penetration was developed using the Log-Normal Distribution. The variation of the attenuation per floor, room and building type were analysed. The results showed an average attenuation of $5.7 \mathrm{~dB}$ for GSM900 with a standard deviation of $11.1 \mathrm{~dB}$. Though, there was a model to predict signal attenuation, but their emphasis was on building floor losses and nothing was said about penetration loss associated with the building wall and roof. Also, their work was basically on the comparison of GSM 900 and GSM 1800 signal strengths.

In the work reported in [11], measured data and empirical models for $5.85 \mathrm{GHz}$ radio propagation path loss in and around residential areas were carried out.
In their report, three homes and two stands of trees were studied for outdoor path loss, tree loss, and house penetration loss in a narrowband measurement campaign that included 270 local area path loss measurements and over 276,000 instantaneous power measurements. Their results could be useful in future wireless planning but there was no evidence that the building pattern contributed to either signal loss or gain.

In [4], the variations of signal strength in terms of shadow or multi path fading using Log normal and Rayleigh distribution were encountered. They conducted measurements at the center of a football pitch of Adamawa state University, Mubi in two weeks from $10 / 01 / 2010$ - 24/01/2010; total of 700 observations were made altogether for two GSM operators namely Glo and Zain, their investigation revealed that GSM signal strength was attenuated at the chosen location (where the signal is received) due to the fading phenomenon and the overall result established that the GSM signal strength received at Adamawa State University was fairly adequate but not sufficient enough to meet up with customer's demand. There results did not show the impact of building loss as well as penetration loss.

In the work by [6] measurements were conducted to prove the outages that GSM signals experience at some indoor locations even when there are strong outdoor receptions. This they said is often traced to the building penetration loss, which accounts for increased attenuation of received GSM signal level when a mobile signal device is moved indoor from outdoor. The signal degradation increases with increasing penetration loss. Penetration loss depends on the building material type, amongst others and adds to the overall path loss of a link. Measurements of two existing GSM Operators' signals level were made outside and inside two selected buildings- concrete and block, which represent the prevalent building types in Orhuwhorun, Delta State, Nigeria. A Samsung Galaxy GT-35000 mobile phone with RF signal tracker software installed in it was used and the results shows an average loss of $10.62 \mathrm{dBm}$, and $4.25 \mathrm{dBm}$ for the concrete and block buildings, respectively. Despite the fact that their measurements considered only concrete and block walls, there results did not account for penetration loss through different wall pattern and roof. 


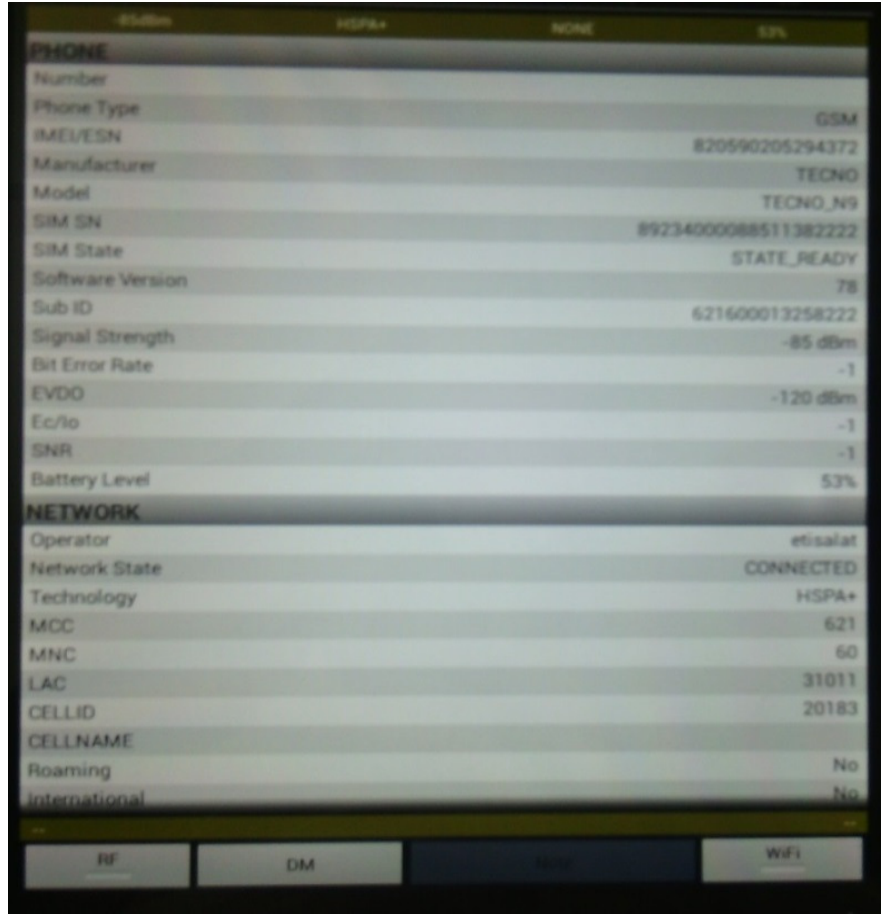

Figure 1: Tecno Tablet MS showing RFST Software data

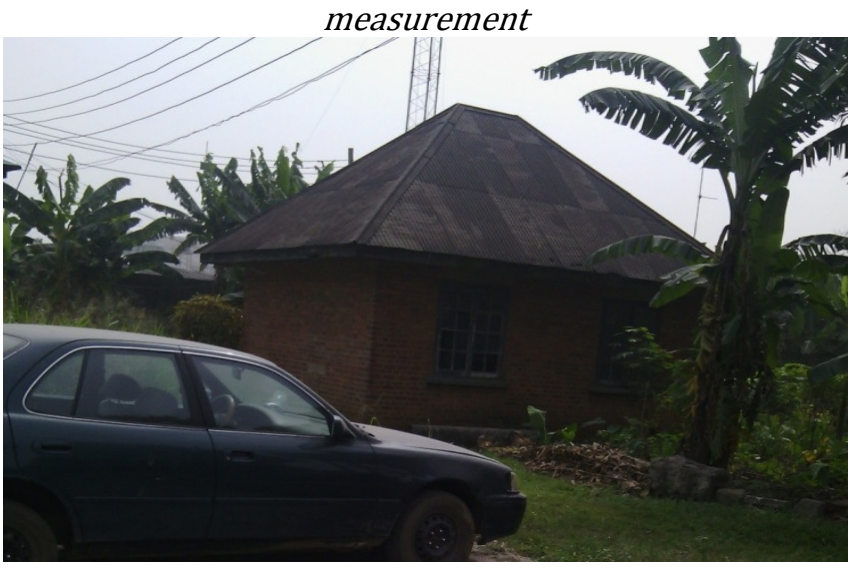

Figure 3: Mud House with Rusted Corrugated Iron Roof Sheet

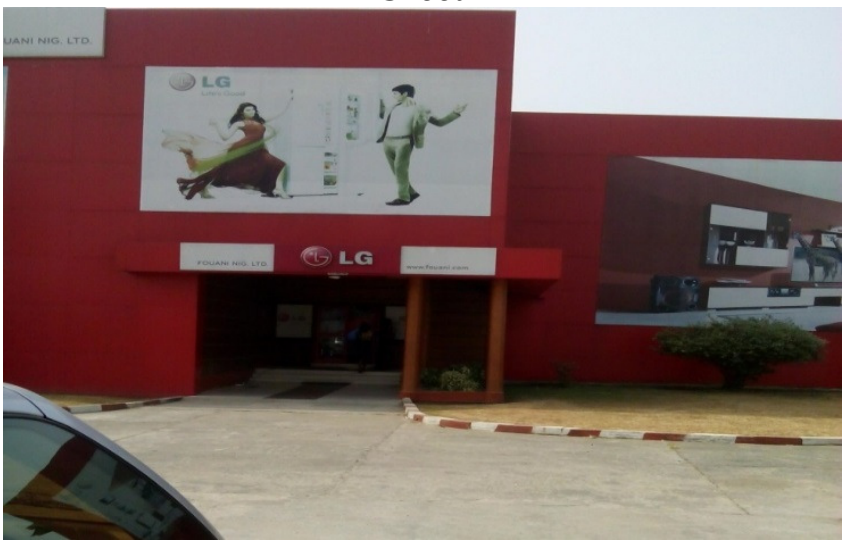

Figure 5: Building with Alucoboard Wall Cladding

\section{MATERIALS AND METHOD}

The methodology involved measurements conducted on five different buildings in four different locations

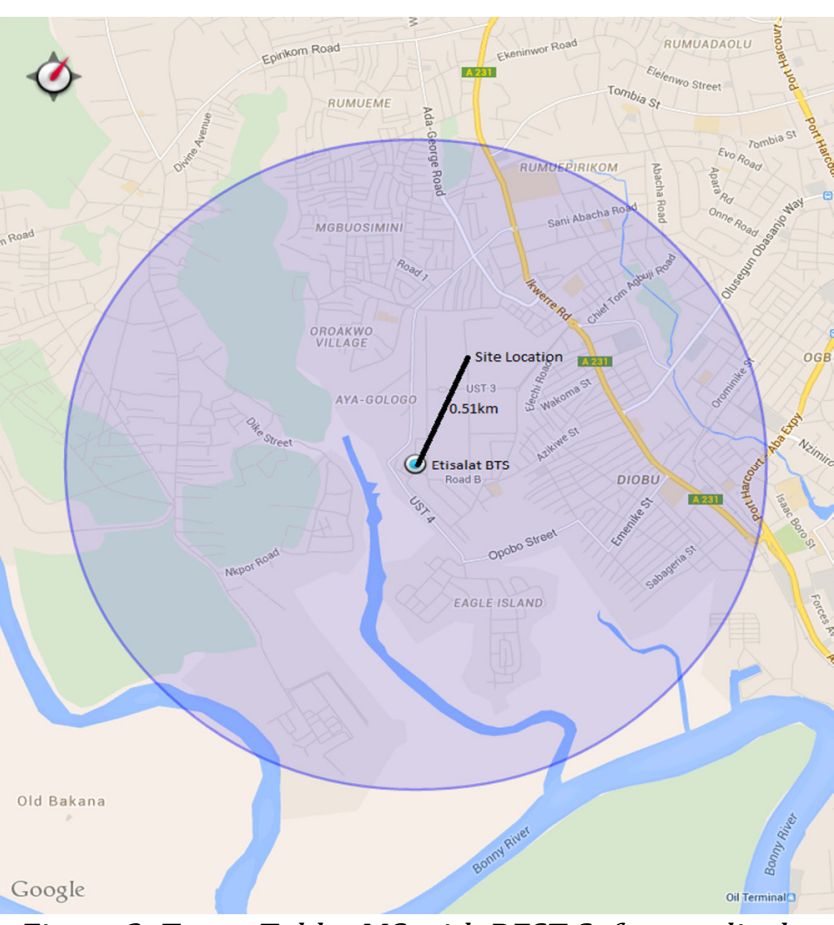

Figure 2: Tecno Tablet MS with RFST Software display of measurement site location

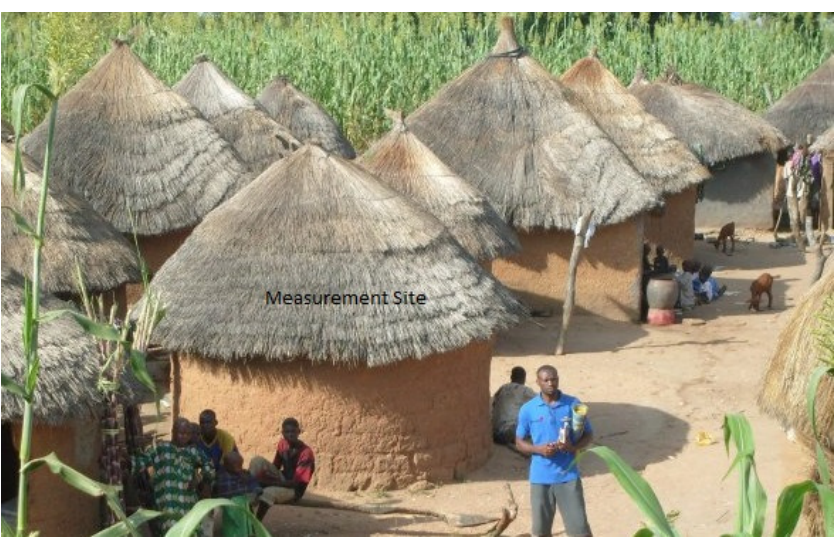

Figure 4: Mud House with Thatched Roof

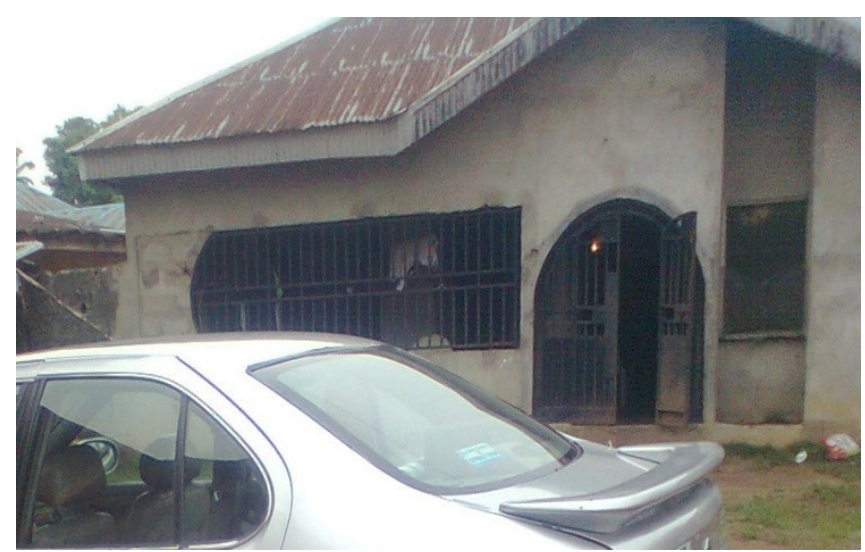

Figure 6: Sandcrete Building with Rusted Corrugated Iron Sheet Roof

(Port Harcourt, Elele, Omoku and Emohua) all in Rivers State, Nigeria. The study was carried out on four GSM service providers (MTN, Etisalat, Globacom and Airtel), 
to determine their signal penetration through buildings made of different materials using Radio Frequency Signal Tracker (RFST) software. A Tecno Tablet installed with Radio frequency Signal Tracker was used in carrying out the measurements to determine the signal strength, signal-to-noise ratio (SNR) and the distance from the measurement site to the Base Transceiver Stations (BTS).

The measurements conducted in each of the four different locations were conducted on five buildings made of different materials namely, mud building with thatched roof, mud building with rusted corrugated iron sheet roof, sandcrete building with unrusted corrugated iron sheet roof, sandcrete building with rusted corrugated iron sheet roof and building with Alucoboard wall cladding.

\subsection{Description of Measurement Sites}

The measurement locations comprised different buildings as stated in section 2 . In each location, sixty measurements were conducted in thirty different days (twice for each day, morning and evening) on each of the building pattern namely: mud building with rusted corrugated iron sheet roof, mud building with thatched roof, sandcrete building with rusted corrugated iron sheet roof, sandcrete building with unrusted corrugated iron sheet roof and building with Alucoboard wall cladding. Figure 1 is a display of one of the measurements conducted on etisalat network while figure 2 is the geographical location of the measurement site as displayed on the RFST software. In each of the buildings, measurements were first conducted outside the building before the inside measurements, this is to ascertain accurate measurement of the wall penetration loss. Figure 3 through 6 respectively is the buildings in which the measurements were conducted.

\subsection{Calculation of Penetration Loss}

For each of the measurements, the wall penetration loss was computed as:

$$
A_{\text {pen-loss }}(\mathrm{dBm})=S_{\text {out }}(\mathrm{dBm})-S_{\text {in }}(\mathrm{dBm})
$$

Where $A_{\text {pen-loss }}$ the average penetration loss in $\mathrm{dBm}$ is, $S_{i n}$ is the average signal strength inside the building in $\mathrm{dBm}$ and $S_{\text {out }}$ is the average signal strength outside the building in $\mathrm{dBm}$. The dimensions of the buildings were not considered since there were many buildings under study, but their surroundings as the physical surroundings around and within any building also affect the signal strength. The positions of the transmitter (BTS) and the dimensions of the window area were considered, as measurements were not conducted on buildings with many and large window areas. Table 1 is the average distance from the network BTS to measurement site.

Table 1: Average Distance from BTS to measurement site

\begin{tabular}{|c|c|c|c|c|c|c|}
\hline \multirow[b]{2}{*}{ Locations } & \multirow[b]{2}{*}{$\begin{array}{l}\text { Network } \\
\text { Provider }\end{array}$} & \multicolumn{5}{|c|}{ Average Distance From BTS to Building $(\mathrm{m})$} \\
\hline & & $\begin{array}{l}\text { Mud Building with } \\
\text { Rusted Corrugated } \\
\text { iron sheet roof }\end{array}$ & $\begin{array}{l}\text { Mud Building } \\
\text { with Thatched } \\
\text { roof }\end{array}$ & $\begin{array}{c}\text { Sandcrete Building } \\
\text { with Rusted } \\
\text { Corrugated iron sheet } \\
\text { roof }\end{array}$ & $\begin{array}{c}\text { Sandcrete Building } \\
\text { with Unrusted } \\
\text { corrugated iron sheet } \\
\text { roof }\end{array}$ & $\begin{array}{l}\text { Building with } \\
\text { Alucoboard wall } \\
\text { Cladding }\end{array}$ \\
\hline \multirow{4}{*}{ Elele } & MTN & 528 & 845 & 452 & 925 & 618 \\
\hline & Globacom & 512 & 515 & 512 & 845 & 458 \\
\hline & Etisalat & 856 & 822 & 456 & 452 & 1022 \\
\hline & Airtel & 468 & 485 & 541 & 869 & 511 \\
\hline \multirow{4}{*}{$\begin{array}{c}\text { Port } \\
\text { Harcourt }\end{array}$} & MTN & 856 & 584 & 648 & 941 & 1033 \\
\hline & Globacom & 645 & 547 & 589 & 412 & 848 \\
\hline & Etisalat & 1322 & 942 & 841 & 641 & 1024 \\
\hline & Airtel & 1022 & 984 & 451 & 641 & 842 \\
\hline \multirow{4}{*}{ Emohua } & MTN & 1032 & 647 & 815 & 941 & 944 \\
\hline & Globacom & 625 & 678 & 812 & 914 & 547 \\
\hline & Etisalat & 925 & 841 & 547 & 687 & 598 \\
\hline & Airtel & 546 & 555 & 465 & 784 & 1021 \\
\hline \multirow{4}{*}{ Omoku } & MTN & 354 & 398 & 648 & 699 & 854 \\
\hline & Globacom & 845 & 547 & 665 & 542 & 1021 \\
\hline & Etisalat & 655 & 847 & 974 & 1033 & 689 \\
\hline & Airtel & 765 & 947 & 1021 & 874 & 982 \\
\hline
\end{tabular}




\subsection{Least Square Line Analysis}

Having computed the received powers and their corresponding distances from the BTS, the least square line method was used to obtain the line of best fit because the best fit curve has the minimal sum of the deviation squared for a given set of data.

The least square line approximating the set of points $\left(\mathrm{x}_{1}, \mathrm{y}_{1}\right),\left(\mathrm{x}_{2}, \mathrm{y}_{2}\right) \ldots\left(\mathrm{x}_{\mathrm{n}}, \mathrm{y}_{\mathrm{n}}\right)$ is represented in equation (2) [10].

$$
y=a x+b
$$

To approximate the set of data $\left(\mathrm{x}_{1}, \mathrm{y}_{1}\right),\left(\mathrm{x}_{2}, \mathrm{y}_{2}\right),\left(\mathrm{x}_{3}, \mathrm{y}_{3}\right)$, $\left(\mathrm{x}_{4}, \mathrm{y}_{4}\right), \ldots . .\left(\mathrm{x}_{\mathrm{n}}, \mathrm{y}_{\mathrm{n}}\right)$ where $n \geq 2$; such that the sum of squares of the distances to this straight line $y=a x+b$ from the set of points is a minimum.

$$
b=\frac{\left(\sum_{i=1}^{n} y_{i}\right)\left(\sum_{i=1}^{n} x_{i}^{2}\right)-\left(\sum_{i=1}^{n} x_{i}\right)\left(\sum_{i=1}^{n} y_{i} x_{i}\right)}{n\left(\sum_{i=1}^{n} x_{i}^{2}\right)-\left(\sum_{i=1}^{n} x_{i}\right)}
$$

$$
a=\frac{n\left(\sum_{i=1}^{n} x_{i} y_{i}\right)-\left(\sum_{i=1}^{n} x_{i}\right)\left(\sum_{i=1}^{n} y_{i}\right)}{n\left(\sum_{i=1}^{n} x_{i}^{2}\right)-\left(\sum_{i=1}^{n} x_{i}\right)}
$$

\section{RESULTS AND DISCUSSION}

\subsection{Results}

The Table 2 through table 5 show the measurement results from the various measurement locations.

\section{DISCUSSION}

The results showed that the buildings with alucoboard wall cladding has the highest signal penetration loss, mud building with thatched roof has the second highest signal penetration loss except in Elele where it has less penetration loss

Table 2: Elele Town Signal Strength Loss

\begin{tabular}{cccccc}
\hline \multirow{5}{*}{$\begin{array}{c}\text { Network } \\
\text { Provider }\end{array}$} & $\begin{array}{c}\text { Mud Building with } \\
\text { Rusted Corrugated } \\
\text { iron sheet roof in dBm }\end{array}$ & $\begin{array}{c}\text { Mud Building } \\
\text { with Thatched } \\
\text { roof in dBm }\end{array}$ & $\begin{array}{c}\text { Sandcrete Building with } \\
\text { Rusted Corrugated iron } \\
\text { sheet roof in } \mathrm{dBm}\end{array}$ & $\begin{array}{c}\text { Sandcrete Building with } \\
\text { Unrusted corrugated } \\
\text { iron sheet roof in } \mathrm{dBm}\end{array}$ & $\begin{array}{c}\text { Building with } \\
\text { Alucoboard wall } \\
\text { Cladding in } \mathrm{dBm}\end{array}$ \\
\hline MTN & 12.42 & 15.81 & 28.35 & 31.04 & 38.45 \\
Globacom & 20.22 & 18.32 & 25.65 & 33.41 & 41.14 \\
Etisalat & 48.05 & 34.54 & 29.22 & 39.32 & 44.25 \\
Airtel & 36.12 & 32.47 & 34.21 & 34.24 & 44.15 \\
\hline
\end{tabular}

Table 3: Port Harcourt Signal Strength Loss

\begin{tabular}{cccccc}
\hline \multirow{5}{*}{$\begin{array}{c}\text { Network } \\
\text { Provider }\end{array}$} & $\begin{array}{c}\text { Mud Building with } \\
\text { Rusted Corrugated iron } \\
\text { sheet roof in } \mathrm{dBm}\end{array}$ & $\begin{array}{c}\text { Mud Building } \\
\text { with Thatched } \\
\text { roof in } \mathrm{dBm}\end{array}$ & $\begin{array}{c}\text { Sandcrete Building with } \\
\text { Rusted Corrugated iron } \\
\text { sheet roof in } \mathrm{dBm}\end{array}$ & $\begin{array}{c}\text { Sandcrete Building with } \\
\text { Unrusted corrugated } \\
\text { iron sheet roof } \mathrm{dBm}\end{array}$ & $\begin{array}{c}\text { Building with } \\
\text { Alucoboard wall } \\
\text { Cladding in } \mathrm{dBm}\end{array}$ \\
\hline MTN & 41.05 & 39.98 & 37.31 & 31.48 & 41.22 \\
Globacom & 48.55 & 47.71 & 32.66 & 40.10 & 48.47 \\
Etisalat & 47.50 & 44.21 & 26.25 & 33.05 & 50.25 \\
Airtel & 48.41 & 40.44 & 28.35 & 35.55 & 51.24 \\
\hline
\end{tabular}

Table 4: Omoku Signal Strength Loss

\begin{tabular}{cccccc}
\hline \multirow{5}{*}{$\begin{array}{c}\text { Network } \\
\text { Provider }\end{array}$} & $\begin{array}{c}\text { Mud Building with } \\
\text { Rusted Corrugated } \\
\text { iron sheet roof in } \mathrm{dBm}\end{array}$ & $\begin{array}{c}\text { Mud Building } \\
\text { with Thatched } \\
\text { roof in } \mathrm{dBm}\end{array}$ & $\begin{array}{c}\text { Sandcrete Building with } \\
\text { Rusted Corrugated iron } \\
\text { sheet roof in } \mathrm{dBm}\end{array}$ & $\begin{array}{c}\text { Sandcrete Building with } \\
\text { Unrusted corrugated } \\
\text { iron sheet roof in dBm }\end{array}$ & $\begin{array}{c}\text { Building with } \\
\text { Alucoboard wall } \\
\text { Cladding in dBm }\end{array}$ \\
\hline MTN & 43.72 & 52.10 & 39.42 & 29.21 & 48.23 \\
Globacom & 45.91 & 50.70 & 33.39 & 30.21 & 52.42 \\
Etisalat & 59.47 & 56.42 & 36.47 & 31.10 & 56.25 \\
Airtel & 42.74 & 51.55 & 40.36 & 41.53 & 54.26 \\
\hline
\end{tabular}


Table 5: Emohua Signal Strength Loss

\begin{tabular}{cccccc}
\hline \multirow{2}{*}{$\begin{array}{c}\text { Network } \\
\text { Provider }\end{array}$} & $\begin{array}{c}\text { Mud Building with } \\
\text { Rusted Corrugated } \\
\text { iron sheet roof in dBm }\end{array}$ & $\begin{array}{c}\text { Mud Building } \\
\text { with Thatched } \\
\text { roof in dBm }\end{array}$ & $\begin{array}{c}\text { Sandcrete Building with } \\
\text { Rusted Corrugated iron } \\
\text { sheet roof dBm }\end{array}$ & $\begin{array}{c}\text { Sandcrete Building with } \\
\text { Unrusted Corrugated } \\
\text { iron sheet roof in dBm }\end{array}$ & $\begin{array}{c}\text { Building with } \\
\text { Alucoboard wall } \\
\text { Cladding in dBm }\end{array}$ \\
\hline MTN & 32.70 & 55.12 & 39.42 & 29.71 & 56.20 \\
Globacom & 35.80 & 50.72 & 37.39 & 30.25 & 55.30 \\
Etisalat & 49.50 & 56.41 & 36.47 & 31.10 & 49.24 \\
Airtel & 33.72 & 51.52 & 40.41 & 30.66 & 54.35 \\
\hline
\end{tabular}

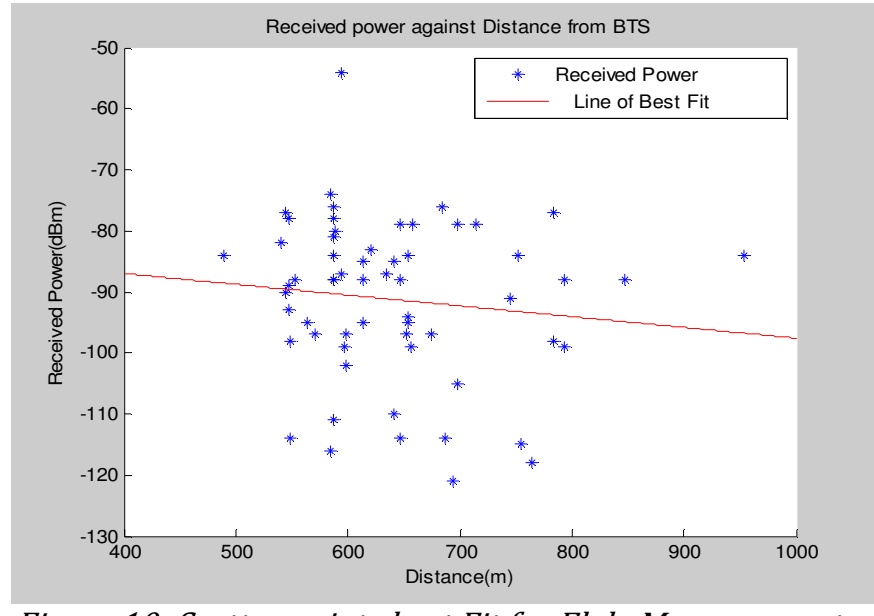

Figure 10: Scatter points best Fit for Elele Measurements

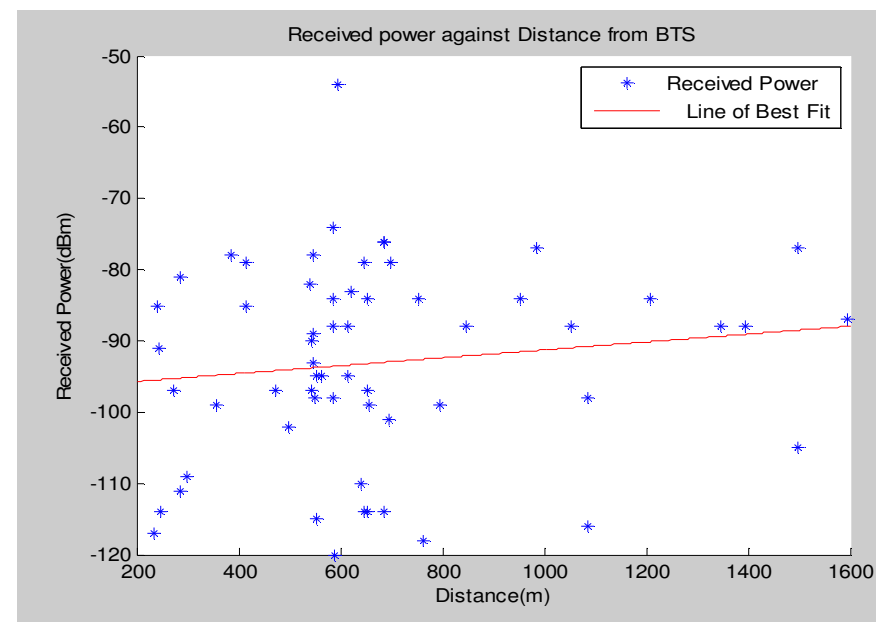

Figure 12: Scatter points best Fit for Omoku Measurements

The sandcrete building with unrusted corrugated iron roof sheet has the least signal penetration loss. Figures 10-13 are the plots of the average received power against the distance from the serving base transceiver station (BTS). The line of best fit as well as the equations and their standard deviation are expressed. At Elele, the Etisalat network has the highest received power of $-54.3 \mathrm{dBm}$ measured in a sandcrete building with unrusted corrugated iron sheet roof and the Airtel network has the least received power of $-122.2 \mathrm{dBm}$ measured in a building with alucoboard wall cladding. Similarly, at Omoku and Port Harcourt, the MTN network has the highest received power of $-53.4 \mathrm{dBm}$

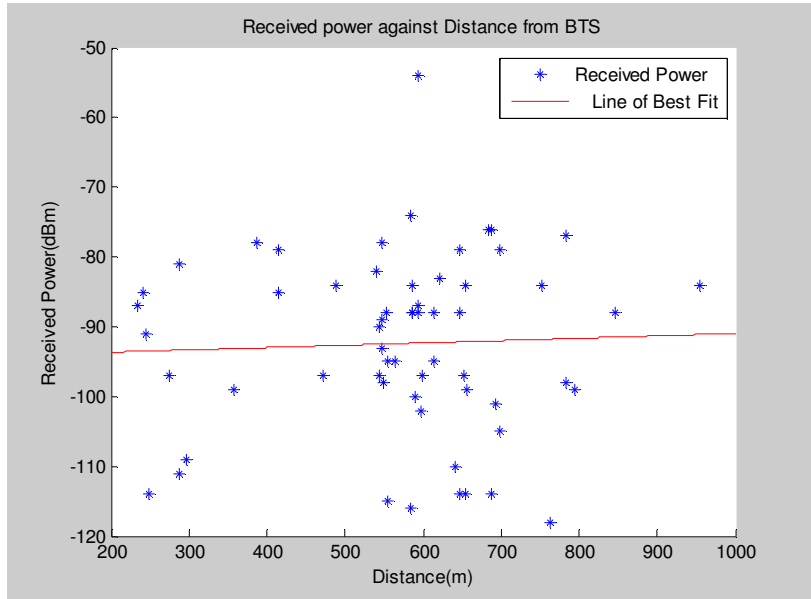

Figure 11: Scatter points best Fit for Port Harcourt Measurements

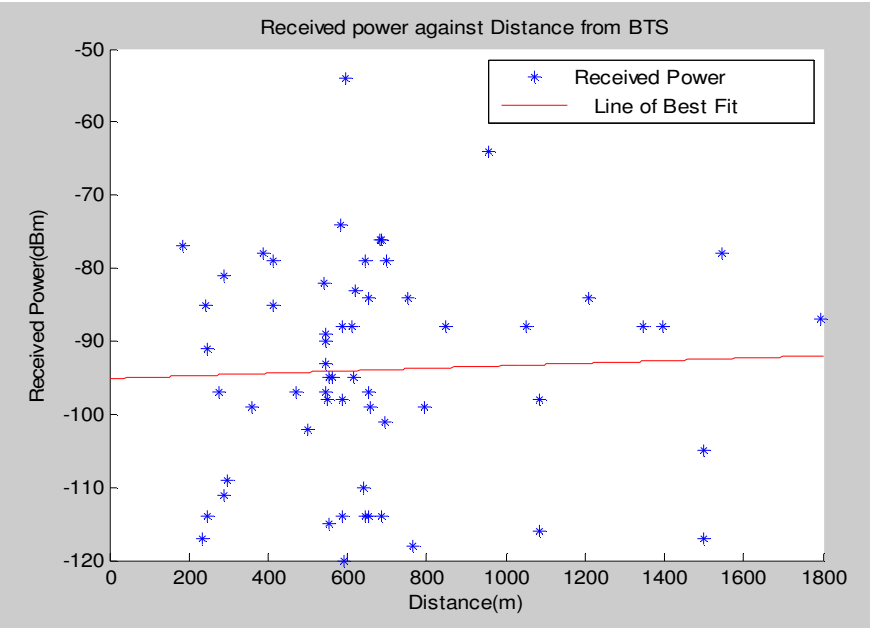

Figure 13: Scatter points best Fit for Emohua Measurements

and $55.2 \mathrm{dBm}$ respectively measured on a sandcrete building with unrusted corrugated iron sheet roof. The Airtel has the least received power in Port Harcourt measured as $-118.7 \mathrm{dBm}$ while Globacom has the least received signal of $-120 \mathrm{dBm}$ in Omoku. In Emohua, the mud house with thatched roof has the least received signal of $-120 \mathrm{dBm}$

Equation of line;

$$
y=-0.017629 x-86.95
$$

This means that for every increase of measurement distance of $1 \mathrm{~m}$, the received signal strength decreases by $0.0017629 \mathrm{dBm}$ and at a minimum distance of 400 
meters from the BTS, the received signal strength is 86.95dBm.

Equation of line;

$$
y=0.0033585 x-94.323
$$

This means that for every increase of measurement distance of $1 \mathrm{~m}$, the received signal strength increases by $0.0033585 \mathrm{dBm}$ and at a minimum distance of 200 meters from the BTS, the received signal strength is $94.323 \mathrm{dBm}$.

Equation of line;

$$
y=0.0055334 x-96.807
$$

This means that for every increase of measurement distance of $1 \mathrm{~m}$, the received signal strength increases by $0.0055334 \mathrm{dBm}$ and at a minimum distance of 200 meters from the BTS, the received signal strength is $96.807 \mathrm{dBm}$.

Equation of line;

$$
y=0.0017304 x-95.093
$$

This means that for every increase of measurement distance of $1 \mathrm{~m}$, the received signal strength increases by $0.0017304 \mathrm{dBm}$ and at the BTS, the received signal strength is $-95.093 \mathrm{dBm}$.

\section{CONCLUSIONS}

The results showed the effect of building materials/pattern on GSM downlink signals power losses. As the mobile equipment (phone) is moved from outside to inside the building, the path loss increases and the penetration loss of the GSM signal is a function of building wall/roof material. The results showed that the building with alucoboard wall cladding has the highest signal penetration loss while the sandcrete building/unrusted corrugated iron sheet roof has the lowest signal penetration loss.

To minimize this building losses; there is need to improve the sensitivity of the receiver by increasing the receiver antenna element. Secondly the use wimax as an optimal combiner in houses will eliminate these building penetration losses. Lastly, builders should eliminate the use of aesthetic materials that can reduce signal strength such as alucoboard in beautifying houses.

\section{REFERENCES}

[1] Adewoye, J. 0. and Obasa, K. A. (2010): Impact of Global System for Mobile Communication on Small Business Development, Journal of Management and Society 1(2): 44-50.

[2] Rappaport, T. S. (2003): Wireless Communications: Principles and Practice, 2nd ed. Pearson Education PTE Ltd, Singapore, 105-167.

[3] Okamoto, H., Kitao, K. and Ichitsubo, S. (2009): Outdoor-to-Indoor Propagation Loss Prediction in $800 \mathrm{MHz}$ to $8 \mathrm{GHz}$ Band for an Urban Area, IEEE Trans on Veh. Technology, 58(3): 1058-1067.

[4] Shalangwa, D.A. and Singh, K.S. (2011): Monitoring and Evaluation of Global System for Mobile Communication (GSM) Signal Strength at $900 \mathrm{MHz}$ in Sub Urban Area, International Journal of Computer Science and Network Security, 11(10): 175-177.

[5] Ferreira, L., Kuipers, M., Rodrigues, C. and Correia, L.M. (2012): Characterisation of Signal Penetration into Buildings for GSM and UMTS, Technical University of Lisbon. 2-3

[6] Idim, A.I. and Anyasi, F.I. (2014): Determination of Building Penetration Loss of GSM Signals, IOSR Journal of Electronics and Communication Engineering, 9(5): 1-5.

[7] Danladi, T.A., Lawan, A.U. and Aderinola, M. (2013): Studies and Effects of Building Pattern on Downlink Mobile Phone Signal Strengths and Power Loss, IJES journals, 2(12): 24-29.

[8] Ångskog, P. (2012): Measurement and Analysis of Radio Wave Coverage in Industrial Environments, Master's Thesis, University of Gavle, 5-7.

.[9] Ogbulezie, J.C., Onuu, M.U., Bassey, D.E. and EtienamUmoh, S. (2013): Site Specific Measurements and Propagation Models for GSM in three Cities in Northern Nigeria, American Journal of Scientific and Industrial Research, 4(2): 238-245.

[10] Gupta, S.C. (2011): Fundamentals of Statistics, Himalaya Publishing House, PVT. Ltd, 6th edition: 810.

[11] Durgin, G., Rappaport, T.S. and Hu, H. (2002): Radio Path Loss and Penetration Loss Measurements in and around Homes and Trees at 5.85GHz, Mobile and Portable Radio Research Group: 1-4. 